\title{
Oxygen physiology: sensors and ion channels
}

\author{
Yasuo Mori $^{1,2} \cdot$ Nobuaki Takahashi $^{1,3} \cdot$ Nozomi Ogawa $^{1} \cdot$ Thomas Gudermann $^{4,5,6}$
}

Received: 12 November 2015 / Accepted: 16 November 2015 /Published online: 21 November 2015

(C) The Author(s) 2015. This article is published with open access at Springerlink.com

Ever since Pflüger, it has been always a major issue of physiology to identify the core principles underlying our body's ability to sense and adapt to the changes in the availability of ambient molecular oxygen $\left(\mathrm{O}_{2}\right)[3,5]$. The milestone discovery of an $\mathrm{O}_{2}$ sensor was first achieved at the organ level by Heymans, who demonstrated that inspired hypoxia triggers increased breathing through the stimulation of the carotid bodies (CBs) [2]. With regard to the cellular and molecular mechanisms underlying the acute hypoxia-sensing in the CBs, it is generally accepted that hypoxia inhibits $\mathrm{K}^{+}$channels to depolarize the chemoreceptor glomus cells, leading to the activation of voltage-dependent $\mathrm{Ca}^{2+}$ channels and consequent release of neurotransmitters that relays information to regulate the respiration [10]. Another milestone is the discovery of a soluble factor erythropoietin (Epo) that is essential for the chronic phases of $\mathrm{O}_{2}$ adaptation. At the end of nineteenth

Yasuo Mori

mori@sbchem.kyoto-u.ac.jp

1 Laboratory of Molecular Biology, Department of Synthetic Chemistry and Biological Chemistry, Graduate School of Engineering, Kyoto University, Kyoto 615-8510, Japan

2 Laboratory of Environmental Systems Biology, Department of Technology and Ecology, Hall of Global Environmental Studies, Kyoto University, Nishikyo-ku, Kyoto 615-8510, Japan

3 Department of Cell Biology, Harvard Medical School, Boston, MA 02115, USA

4 Walther-Straub-Institute for Pharmacology and Toxicology, Ludwig-Maximilians University, Munich, Germany

5 Comprehensive Pneumology Center Munich (CPC-M), German Center for Lung Research, Munich, Germany

6 DZHK (German Centre for Cardiovascular Research), Munich Heart Alliance, Munich, Germany century, it was recognized by Viault that exposure to high altitude hypoxia elicits a robust burst of erythropoiesis in humans [1]. Almost a half century later, Epo was demonstrated to mediate hypoxia-induced erythropoiesis. While the initial characterizations of the expression of Epo suggested its production in the fetal liver and adult kidney, it was only recently that the localization of the renal Epo-producing (REP) cell was found to be in the peritubular interstitial space located in the deep renal outer medulla region [4]. In addition, hypoxia-inducible factor (HIF) [6] is recognized as the transcription factor central to chronic cellular responses to hypoxia including erythropoiesis via Epo production. Thus, CBs, Epo, and HIF provide solid bases for understanding the body's ability to sense and adapt to the ambient $\mathrm{O}_{2}$.

Even after the above discoveries of the core principles, the physiology of $\mathrm{O}_{2}$ sensing and adaptation never loses its glory. This is highlighted by recent findings concerning the diversity and ubiquity of $\mathrm{O}_{2}$-sensing mechanisms. For example, in addition to multiple $\mathrm{K}^{+}$channel subtypes and mediators previously reported responsible for hypoxia sensing, transient receptor potential (TRP) cation channels have emerged as $\mathrm{O}_{2}-$ regulated ion channels critical for $\mathrm{O}_{2}$ sensing in non-CB chemoreceptors and tissues [7, 11]. Importantly, HIF, which binds to the hypoxia-responsive element present in the $3^{\prime}$ enhancer region of the Epo gene [6], is expressed widely throughout the body and is intriguingly found in lower organisms that produce neither Epo nor red blood cells. In addition to erythropoiesis, chronic hypoxia induces the expression of numerous genes whose products facilitate non-oxidative synthesis of ATP and multiply the number of vessels supplying the hypoxic area of tissues [8] through the action of HIFs. These lines of evidence suggest the ubiquitous presence of $\mathrm{O}_{2}$-sensing cells and organs in the animal body. In this context, it is interesting to note that two HIF isoforms HIF1 and HIF2 play distinctive roles in the regulation of hypoxic responses of 
CBs by differentially promoting cellular redox status [12]. Moreover, the physiological importance of hypoxia has been demonstrated in maintaining the hematopoietic stem cell niche for cell cycle quiescence through the action of HIF in the bone marrow [9]. In this special issue, reviews of these recent developments are included together with several important original research articles, which indeed enrich our knowledge in $\mathrm{O}_{2}$ physiology.

We believe that there is a great prospect that $\mathrm{O}_{2}$ physiology will further enhance its current status as a major issue in physiology. A future direction of $\mathrm{O}_{2}$ physiology is systems physiology, in which regulation of $\mathrm{O}_{2}$ sensing and adaptation through interplays among different chemoreceptors and molecules are studied. Another possible direction is to understand $\mathrm{O}_{2}$ sensing and adaptation in the context of redox biology, where alterations in redox homeostasis (via reactive chemical species and antioxidant systems) in response to changes in the $\mathrm{O}_{2}$ availability are integrated with other types of stress such as metabolic perturbation, heat, and proinflammatory mediators. Adding these future developments to $\mathrm{O}_{2}$ physiology should lead us to understand our body's ability as a total system to adapt to changes in ambient $\mathrm{O}_{2}$ availability.

Open Access This article is distributed under the terms of the Creative Commons Attribution 4.0 International License (http:// creativecommons.org/licenses/by/4.0/), which permits unrestricted use, distribution, and reproduction in any medium, provided you give appropriate credit to the original author(s) and the source, provide a link to the Creative Commons license, and indicate if changes were made.

\section{References}

1. Franke K, Gassmann M, Wielockx B (2013) Erythrocytosis: the HIF pathway in control. Blood 122:1122-1128

2. Heymans C, Bouckaert JJ, Dautrebande L (1931) Sinus carotidien et reflexes respiratoires; sensibilite'des sinus carotidiens aux substances chimiques. Action stimulante respiratoire re'flexe du sulfure de sodium, du cyanure de potassium, de la nicotine et de la lobe'line. Arch Int Pharmacodyn Ther 40:54-91

3. Neubauer JA (2004) Comroe's study of aortic chemoreceptors: a path well chosen. J Appl Physiol 97:1595-1596

4. Pan X, Suzuki N, Hirano I, Yamazaki S, Minegishi N, Yamamoto $M$ (2011) Isolation and characterization of renal erythropoietinproducing cells from genetically produced anemia mice. PLoS One 6:e25839

5. Pflüger E (1868) Ueber die Ursache der Athembewegungen, sowie der Dyspnoë und Apnoë. Pflügers Arch Gesamte Physiol Meschen Tiere 1(61-106): 1868

6. Semenza GL, Wang GL (1992) A nuclear factor induced by hypoxia via de novo protein synthesis binds to the human erythropoietin gene enhancer at a site required for transcriptional activation. Mol Cell Biol 12:5447-5454

7. Takahashi N, Kuwaki T, Kiyonaka S, Numata T, Kozai D, Mizuno Y, Yamamoto S, Naito S, Knevels E, Carmeliet P, Oga T, Kaneko S, Suga S, Nokami T, Yoshida J, Mori Y (2011) TRPA1 underlies a sensing mechanism for O2. Nat Chem Biol 7:701-711

8. Takahashi N, Mori Y (2014) The $\mathrm{O}_{2}$-sensing TRPA1 channel illustrates the significance of vagal nerves in cardio-respiratory adaptation to hypoxia. Acta Physiol 210:705-707

9. Takubo K, Goda N, Yamada W, Iriuchishima H, Ikeda E, Kubota Y, Shima H, Johnson RS, Hirao A, Suematsu M, Suda T (2010) Regulation of the HIF-1alpha level is essential for hematopoietic stem cells. Cell Stem Cell 7:391-402

10. Weir EK, López-Barneo J, Buckler KJ, Archer SL (2005) Acute oxygen-sensing mechanisms. N Engl J Med 353: 2042-2055

11. Weissmann N, Dietrich A, Fuchs B, Kalwa H, Ay M, Dumitrascu R, Olschewski A, Storch U, y Schnitzler MM, Ghofrani HA, Schermuly RT, Pinkenburg O, Seeger W, Grimminger F, Gudermann T (2006) Classical transient receptor potential channel 6 (TRPC6) is essential for hypoxic pulmonary vasoconstriction and alveolar gas exchange. Proc Natl Acad Sci U S A 103:1909319098

12. Yuan G, Peng YJ, Reddy VD, Makarenko VV, Nanduri J, Khan SA, Garcia JA, Kumar GK, Semenza GL, Prabhakar NR (2013) Mutual antagonism between hypoxia-inducible factors $1 \alpha$ and $2 \alpha$ regulates oxygen sensing and cardiorespiratory homeostasis. Proc Natl Acad Sci U S A 110: E1788-E1796 